\title{
MULTIPLE-UNIT FRANCHISING AND PERFORMANCE OUTCOMES
}

\author{
Kelli Bodey ${ }^{1}$, Scott Weaven ${ }^{2}$, Debra Grace ${ }^{3}$ \\ Department of Marketing, Griffith Business School, Gold Coast Campus, Griffith University, \\ PMB 50 Gold Coast Mail Centre, Queensland 9726, Australia \\ E-mails: ${ }^{1}$ k.bodey@griffith.edu.au (corresponding author); \\ ${ }^{2}$ s.weaven@griffith.edu.au; ${ }^{3}$ d.grace@griffith.edu.au
}

Received 15 May 2012; accepted 09 July 2012

\begin{abstract}
The economic and social contribution of franchising is widely reported. Although, most studies have examined franchising from the single-unit typology, multipleunit franchising is found to be a popular and pervasive retailing strategy throughout the world. Despite this, there is a paucity of prior research examining the factors influencing the achievement of the four franchising imperatives. This represents an important gap in the organizational choice literature. Therefore, this study empirically examines the impact of the four franchising imperatives (i.e. unit growth, system uniformity, local responsiveness and system wide adaptation) (Bradach 1995) upon franchise system operational performance across the four key governance structures (i.e. master franchising, area development franchising, area representative franchising and incremental franchising). Based on a sample of 347 Australian franchisors, the findings indicate that there are significant differences in the way in which three of the four imperatives (i.e. unit growth, system uniformity and system-wide adaptation) impact on performance across different governance structures. Practical and managerial implications and future research direction are discussed.
\end{abstract}

Keywords: multi-unit franchising, plural governance, four imperatives, Australia, franchise performance.

Reference to this paper should be made as follows: Bodey, K.; Weaven, S.; Grace, D. 2013. Multiple-unit franchising and performance outcomes, Journal of Business Economics and Management 14(Supplement 1): S279-S312.

JEL Classification: M1: Business Administration; Business Administration: General M10.

\section{Introduction}

The economic importance of franchising in service provision, job creation and selfemployment opportunities is widely reported (Dant et al. 2008). In the United States, some 1500 franchise systems provide $\$ 1.53$ trillion to the local economy and employ approximately 18 million people which equates to 11 percent of total private sector payroll (Reynolds 2004). Similar contributions are evident within the United Kingdom, in which an estimated 759 business format franchises account for over one third of all retail sales (British Franchise Association/Natwest 2006). Although servicing a smaller 
population, the Australian franchise sector comprises 1025 franchise systems, boasts an annual turnover of $\$ 128$ billion and has grown at the rate of 12.6 percent during the 2008-2010 period (Frazer et al. 2010). Thus the contribution of franchising to many local economies is substantial.

However, although multiple-unit franchising (MUF) (in which franchisees are permitted to own and operate more that one outlet in a franchise system) is recognised as a pervasive organisational form in franchise systems throughout the world (Kaufmann, Dant 1996; Garg et al. 2005), much of the extant literature retains a single-unit franchising (SUF) focus (Kaufmann, Dant 1996). This is surprising given that much of the future growth in franchising has been attributed to the popularity of MUF arrangements (Dant et al. 2007; Grünhagen, Dorsch 2003; Weaven et al. 2009). Although previous research has touted the value of MUF in promoting rapid unit growth, system-wide adaptation to competitive influences, 'mini-chain' economies of scale and scope, reducing franchisee opportunistic behaviours, minimising rates of franchisee attrition, and strategic advantages derived through delegating price and quality decisions to the unit level (Bercovitz 2003; Dant et al. 2008; Kalnins, Lafontaine 2004; Shane 2001), the literature pertaining to MUF 'can at best be characterised as fragmented and scant' (Dant et al. 2009: 3).

Apart from explicating the strategic benefits of MUF strategies, other franchising scholars have focused upon the motivations and incentives governing MUF adoption (e.g. Grünhagen, Mittelstaedt 2002), discerning differences between single-unit and multipleunit operations (e.g. Kalnins, Lafontaine 2004; Weaven, Frazer 2006; Watson et al. 2007), and exploring the challenges that franchise chains encounter when employing a MUF framework (e.g. Bradach 1995; Garg et al. 2005). However, one central area which very few studies have considered is that of operational performance from a multiple-unit franchising perspective. Studies by Bradach (1995) and Garg et al. (2005) have identified key management challenges or strategic imperatives (that is, unit growth, system uniformity, local responsiveness and system-wide adaptation) found to afford multipleunit franchisees greater performance advantages than single unit franchisees. However their approach has been bound by either exploratory, field data or a lack of application to all four multiple-unit organisational structures (i.e. master franchising, area development arrangements, area representative arrangements and incremental franchising).

This article is offered towards filling this significant void in the literature. The goal of the paper is to empirically examine the influence of the four franchising imperatives (that is, unit growth, system uniformity, local responsiveness and system-wide adaptation) upon franchise system performance across four common multiple unit franchising forms (that is, master franchising, area development arrangements, area representative arrangements and incremental franchising). Hence, the paper seeks to (1) empirically examine the influence of the four franchising imperatives upon operational performance and (2) compare and contrast the influence of the four strategic imperatives upon operational performance across all four MUF forms. The empirical results are drawn from a broad-based franchisee survey conducted within Australia. The paper concludes with implications for theory, practitioners and future academic researchers. 


\section{Literature review}

\subsection{Dependency theory}

Much research exploring the relationships between firms within channels of distribution has done so from the perspective of dependence. Dependence has constantly been found to explain inter-organizational behaviors (e.g. Morgan, Hunt 1994) by providing explanation in terms of the distribution of labor within firm arrangements (Dant, Gundlach 1998). For example, Frazier and Summers (1986) suggest that channel partners have the ability to assign and execute their distinctive roles more effectively as each party has a vested interest in the welfare of the other. In doing so, both parties have the opportunity to receive substantial rewards in return for effective cooperation (Frazier, Summers 1986).

From a research context perspective and, more so within the channel literature, dependence has consistently been linked to power, conflict and satisfaction (Burkle, Posselt 2008; Davies et al. 2009; Frazier, Summers 1986). Typically, justification is found through the theoretical arguments proposed by Emerson (1962). Emerson (1962) argues that dependence is the inverse of power between Firm A and Firm B. As such, dependency is characterized by two interrelated factors of (1) the motivational goals mediated by $\mathrm{B}$ on behalf of A and, (2) inversely proportional to the availability of such goals to A outside the A-B relationship (Emerson 1962).

The relationship common between Firm A and Firm B implies that dependency can play an important role within the context of franchising. From a franchising viewpoint, dependency appears to be a relatively obvious proposition given the foundations born through the franchisor-franchisee relationship. Specifically, the franchisor-franchisee relationship implies that a contractual and on-going arrangement exists between two parties (i.e., the franchisor; the franchisee) both of which have a vested interest in the role each play. For example, franchisees are expected to implicitly uphold the franchisors' brand(s), to facilitate growth (Roh, Andrew 1997), development and expansion of the franchise system, to overcome local competition and enhance profitability through franchising fees and on-going royalties (Justis, Judd 1986). In contrast, franchisees also presume that the franchisor will actively participate in enabling the achievement of such growth, development and expansion through initial and on-going training, services and support, in addition, to enacting proven operating procedures. This, in contrast, surpasses the costs of establishing a new brand (similar to initiating a new business venture); often restrained by financial resources and market place presence. Foremost, given the interrelated nature of the franchisor-franchisee relationship, we expect that dependency will play a focal role from a MUF perspective and, as such is used as the overarching theoretical framework for this study.

\subsection{Multiple-unit franchising}

MUF is not a single organisational form and, is therefore, characterised as 'franchising in which the franchisee can operate many units' (Garg et al. 2005: 188). Both Kaufmann and Dant (1996), Kalnins and Lafontaine (2004) contend that the area of MUF has been relatively unexplored and limited in the realms of its focus and, as such, remains in 
part, a 'curious anomaly' in franchising research (Kaufmann, Dant 1996: 346). Despite the growth of research within the multiple-unit franchising realm, studies have been limited to MUF and system growth (e.g. Kaufmann, Kim 1995), system adaptability (Garg et al. 2005) and incentives and strategic motives (Grünhagen, Mittelstaedt 2002; Kalnins, Lafontaine 1999; Weaven, Frazer 2006, 2007).

On the face of it, MUF appears to contradict the traditional view of franchising (Garg et al. 2005). From an agency theoretic perspective, MUF remains a curious anomaly as several MUF arrangements (such as area developers and sequential multipleunit franchisees) introduce additional levels of management whereby individual store managers are required (Garg et al. 2005; Kalnins et al. 2006; Kaufmann, Dant 1996; Kaufmann, Kim 1993, 1995; Sen 1998). Subsequently, hierarchical problems arising from sub-optimal effort at the local market level (and the concomitant need for greater employee monitoring on the part of the multiple unit franchisee) result (Gómez et al. 2010). Therefore, multiple-unit franchising emerges as an organisational form which encourages company-ownership (Kaufmann 1996), thus challenging the core rationale for franchising.

Past research presents agency arguments attributing operational performance measures to traditional single-unit franchising arrangements (e.g. Brickley, Dark 1987; Caves, Murphy 1976; Norton 1988). However, studies in Australia and the United States suggest that the majority of franchise networks consist of multiple-unit arrangements (Frazer et al. 2006; Grünhagen, Mittelstaedt 2000; Kaufmann, Dant 1996). Interestingly, multiple-unit franchising presents similar problems to those that are found in the single-unit operation. For example, multiple-unit franchises often encounter problems of moral hazard and adverse selection (e.g. Bradach 1997; Chow, Frazer 2003; Kaufmann, Dant 1996). Furthermore, given that MUF requires unit managers (i.e. area representatives, sub-franchisors) shirking at the local level may impact upon unit-level efficiency.

However, despite the apparent differences, studies have typically examined multipleunit franchising from a holistic perspective as opposed to considering each multiple-unit variant individually (which may influence the performance of one multiple-unit arrangement over another). In order to understand the influence of each multiple-unit arrangement, definitions of each are provided. Master franchising is the occupation of 'an independent business person who has contracted with the franchisor to sell franchises to franchisees in a specific geographic area or territory' (Justis, Judd 1986: 16). Area development franchising is characterized as an agreement by which the area developer maintains the right to open multiple units (Weaven, Frazer 2003), over a pre-specified period of time, within an assigned geographic territory. An area representative is permitted to recruit potential franchisees to a franchise system (Whittemore, Perry 1998) and to assign potential franchisees to a designated area, whilst providing on-going support and services to current franchisees (Lowell 1991). Finally, Incremental franchising is the right to purchase additional franchise units (Kaufmann, Dant 1996) based on their performance of existing franchise unit(s).

The following section provides explanation of the four main forms of multiple-unit franchising arrangements (i.e. incremental franchising, master franchising, area devel- 
opment franchising and area representative franchising) and their likely operational influence across the four franchising imperative defined through the seminal work of Bradach (1995).

\subsection{Unit growth}

Unit growth can be defined as the addition of company units to a system, the addition of franchisees who add several units to a chain and/or the inclusion of additional units to a pre-existing franchisee within the system (i.e. incremental franchising) (Bradach 1995). In terms of MUF, master franchising is recognised as a governance form able to promote rapid system growth (Kalnins 2005; Kaufmann, Kim 1995; Lowell 1991). However, previous research confirms that master franchising has been linked to a decrease in operationally efficiency because there exists an intermediary (i.e., master) between the franchisor and franchisee (Kaufmann, Kim 1995). Often the franchisor has to substitute operating efficiency and brand deterioration for system growth or visa-versa (Kaufmann 1992; Kaufmann, Kim 1995). Given that an additional level of management (i.e. master) is present between the franchisor and franchisee, agency concerns of adverse selection and moral hazard are more prevalent in master franchising arrangements which may further impede growth. For example, the difficulty in acquiring suitable franchisees reduces the speed at which the system can grow.

From an agency perspective, incremental franchising (IF) reduces the occurrence of adverse selection because the franchisor has already undertaken a comprehensive selection process. Consequently, the franchisor is aware of the incremental franchisees behaviour and capabilities to operate an additional unit. Moreover, IF suggests that franchisees have prior unit success and therefore, have demonstrated both operational efficiency and productivity with existing franchise units (e.g., sales volume, franchisee profitability etc.) (Kaufmann, Dant 1996). However, it appears that IF encourages system sustainability as opposed to rapid system growth. For example, whilst IF enhances the rate of growth within a system, Kaufmann and Kim (1995: 55) suggest that the 'sequential nature of expansion' limits the effect of IF. Although, IF would be advantageous in systems where there exists a high number of franchisees, it is assumed that smaller, less developed systems would not be able to grow at a greater rate than other organizational forms (e.g. ADF).

In comparison, ADF arrangements have the capabilities to extend the growth of a system at a more rapid rate than either master franchising or IF. For example, ADF is used to enhance rapid system growth, as an area developer is solely responsible for the growth of units within their assigned territory, including formulization (Garg et al. 2005; Kaufmann, Kim 1993, 1995). Failure to grow would ensure that the area developer would lose both the potential profits from the sale of units and the initial investment they paid for the rights to the territory. In addition, area development arrangements enable the franchisor to train only one area developer rather than a larger more complex number of independent franchisees. Despite Kaufmann and Kim (1995) suggesting that area development arrangements are more involved (i.e. time), require greater training both in management and operation of the system and would restrict the system from 
growing any faster than a single unit franchisee, Garg et al. (2005) found contradictory results. In particular, Garg et al. (2005) found that ADF was preferred over IF when rapid system growth was a key objective. This is supported by previous research suggesting that ADF 'permits parallel development of multiple markets and should speed growth significantly’ (Kaufmann, Kim 1995: 5).

Finally, in comparison to master franchising, IF and ADF, area representatives (AR/s) would be the least likely governance form to achieve rapid system growth. Given that ARs are not granted the right to contract with potential franchisees (Lowell 1991) and only oversee an assigned territory on behalf of the franchisor, the addition of new units/ franchisees is unattainable. On this basis it is hypothesized that:

H1: Unit growth will have a stronger influence on operational performance in area development arrangements than master franchising, area development and incremental franchising arrangements.

\subsection{System uniformity}

System uniformity is defined as the inclusion of standardised practices and processes with minimal variation to the franchise format (Garg et al. 2005). Within a MUF arrangement, uniformity may be better achieved through ADF and area representative agreements as opposed to IF and master franchising (Bradach 1995). Maintaining uniformity appears to require a distinctive set of management expertise's than that of a single unit (Kaufmann, Dant 1996; Grünhagen, Mittelstaedt 2002; Sen 2001). In particular, an incremental franchisee may be dependent on their ability to employ their own multi-tasking skills to achieve performance outcomes to a single unit. As additional units are acquired by the incremental franchisee, they would have to apply their single unit skills to multiple unit operations. Therefore, this would require these franchisees to undergo a transitional period in which to accommodate the addition of multiple-units (Garg et al. 2005). However, the initial intentions of the area developer is to acquire a certain number of units upfront and, therefore, they often have the multi-unit skills (e.g., human resource capabilities and resources) to accommodate a multi-unit arrangement, including addressing system standards of uniformity. From an AR perspective, an AR is required to oversee individual franchisees as well as multiple-unit operators. Therefore, given that AR operate on behalf of the franchisor to guide and monitor franchisee behaviour, system uniformity is likely to be achieved.

Similar to IF, a master franchise arrangement involves the master monitoring the performance of independent franchisees (Justis, Judd 1986). Therefore, it is likely that monitoring of individual franchisees would occur less frequently than in ADF. This is likely to occur as the primary objective of the master franchisee is to enhance unit growth as opposed to monitoring the performance and standards of individual franchisees (Kaufmann, Kim 1995; Stern, El-Ansary 1988). This also creates an environment which encourages franchisee shirking behaviour (i.e., reduce effort) and enables franchisees to deviate from system standards with less effort.

In addition, agency concerns of inefficient investments promote ADF over IF. For example, area developers are aware of the administrative and management tasks involved 
in operating multiple units (Bodipo-Memba, Lee 1997; Kaufmann, Kim 1995). Furthermore, area developers are more willing to invest in additional resources (e.g., managerial and physical) to assist in the achievement of uniformity and further development of their territories/units (Garg et al. 2005). In contrast, the same incentives are not apparent for IF or master franchising. In IF there is no guarantee that they will be awarded additional units and therefore, there is less incentive to invest in further resources. Given that Brickley and Dark (1987) suggest that geographically concentrated units should be collectively owned and operated in an effort to facilitate optimal investment decisions and efficient monitoring, master franchising would support the addition of resources. However, master franchising involves the master growing the system through independent franchisees (Kaufmann, Kim 1995) as opposed to ADF in which the one area developer owns all units within the territory. Therefore, master franchisees may be less willing to forgo additional financial resources to enable greater system uniformity as they will only partially benefit from the on-going royalty of the unit as opposed to all profits as in ADF.

Therefore, systems in which uniformity is crucial, ADF and area representative will be preferred over master franchising and incremental franchising because agency concerns of adverse selection, inefficient investment and free-riding is less problematic. Thus, the following hypotheses are proposed:

H2: Uniformity will have a stronger influence on operational performance in, area development and area representative arrangements than in incremental and master franchising.

\subsection{Local responsiveness}

Local responsiveness is recognized as a means by which organizations demonstrate 'flexibility' (e.g. Pehrsson 2007). In this sense, organizations are characterized as understanding customer needs and adapting to heterogeneous markets. From a MUF perspective both Bradach $(1992,1995)$ and Garg et al. (2005) found that MUF is less suitable for local responsiveness in comparison to SUF. However, both Bradach (1995) and Garg et al. (2005) acknowledge that differences exist in MUF arrangements between $\mathrm{ADF}$ and IF in relation to local responsiveness. For example, single-unit owners are generally required to substantiate their business abilities (prove system success) prior to being granted an additional unit; therefore, it appears plausible that they would have greater local market knowledge in comparison to ADF operators. Moreover, given that single unit operators have greater incentives for local responsiveness (e.g., charge higher prices), it is assumed the same to be true for incremental franchisees. However, an ADF would have less of an incentive because they would be managed by employee managers as opposed to owner operators (i.e. IF). Furthermore, it appears that because additional units are added on a sequential basis, the incremental franchisee is likely to have greater contact with each unit and in accommodating local needs. This also holds for situations in which the incremental franchisee needs to insert an additional layer to the system as it grows (i.e., outlet managers). Therefore, the gradual growth rate pertinent within IF would permit incremental franchisees to have greater control over 
outlet managers enabling the system to adapt even in cases where the system becomes large (Yin, Zajac 2004).

Similar to IF, master franchising would also facilitate local responsiveness. Common within the literature, master franchising is recognised as an organisational form used when entering international markets (e.g., Roh, Andrew 1997; Zietlow, Hennart 1996). In most systems, the franchisor contracts to a local entity or individual in a foreign market as opposed to transferring an individual from the home market (Connell 1997; Pine et al. 2000). As a result, the local entity or individual has considerable local market knowledge assisting the franchisor in the effective implementation of a franchise system, including operating procedures and standards (Kaufmann, Kim 1995; Pine et al. 2000). This ensures that appropriate practices governing a foreign market will be addressed because the master franchisee will have a thorough understanding of what factors may inhibit system suitability within the local market (Dant, Nasr 1998; Doherty, Quinn 1999; Kaufmann, Kim 1995).

Alternatively, AR would be less effective in responding to local conditions. Whilst the AR ensures that franchisees maintain system standards and procedures, often ARs have originated from the home market. This being so, the AR is assigned through the franchisor a specific territory to oversee (Lowell 1991). This suggests that the AR would have limited market knowledge in relation to incremental franchisees and master franchisees where local market knowledge is considerable. Therefore, on this basis the following hypotheses are proposed:

H3: Local responsiveness will have a stronger influence on operational performance in incremental franchising arrangements and master franchising than in area development and area representation arrangements.

\subsection{System-wide adaptation}

From a franchising perspective, adaptation is recognised as a notion closely associated with system uniformity (Garg et al. 2005; Kaufmann, Eroglu 1998). For example, the franchisor has to ensure consistency and the maintenance of system standards (i.e. uniformity) yet permit adaptation to local market conditions without causing harm to the reputation of the brand. Given this, Kaufmann and Eroglu (1998) suggest that franchisors are required to make a trade-off between the benefits of standardisation and the benefits of adaptation which are often necessary to meet the demands of local markets (Kaufmann, Eroglu 1998) and support system success. System-wide adaptation would be preferred in ADF and area representative agreements over IF and master franchising arrangements. Agency problems in relation to system-wide adaptation are particularly pertinent in relation to IF. Agency concerns of information asymmetry and moral hazard would impede the ability of the franchisor to control franchisee behaviour and their willingness to implement organizational processes (Doherty, Quinn 1999; Sen 2001). Whilst, franchisees are required to operate within the stipulations of the contract, independent franchisees may operate in accordance with their own self-interests against the objectives of the franchisor (Bradach 1995; Burgen et al. 1992; Chow, Frazer 2003; Doherty, Quinn 1999; Rassam 1995). In such circumstances, franchisee self-interest 
objectives would be difficult for the franchisor to monitor, particularly in large systems (Doherty, Quinn 1999).

Furthermore, given that incremental franchisees only maintain a small number of units, system-wide adaptation would be difficult and costly to monitor across the entire franchise system, especially in remote locations. For example, if the system comprised of 30 independent units, of which, some occupied additional units (i.e. IF) the franchisor would have to maintain and monitor each independent franchisee (i.e. 30 franchisees). Similarly, master franchising would also be less effective in achieving system-wide adaptation. Moreover, because the master franchisee may sub-lease to independent franchisees (ensuring that each franchisee within that territory adapts system processes) may become problematic. In particular, difficulties may arise because the master franchisee maintains less control over franchisees and, it may be more difficult for the master franchisee to enforce implementation. For example, Bradach (1995) found that individual franchisees often decide whether they wish to implement or choose to ignore a new system initiative and offer support (e.g. Dant, Gundlach 1998; Dant, Nasr 1998).

Alternatively, ADF and area representative franchising are more likely to achieve system-wide adaptation. From an ADF perspective, the area developer is required to own and grow a specific territory with a predetermined number of units. Therefore, under the control of the area developer, franchisors would be able to transfer knowledge (i.e. reducing agency concerns of information asymmetry) and areas in need of adaptation to one area developer, who would subsequently instil information to hired managers throughout that territory. This differs from IF as the franchisor must transfer the information to several independent franchisees and trust that the changes will be implemented. Similarly, from an AR perspective, the AR would enable system-wide adaptation. AR are obligated to work on behalf of the franchisor within a designated territory(s). For this reason, any changes that require modification or adaptation within the chain can be guided and monitored by the area representative. Subsequently, this assures the franchisor that system adaptations are being maintained across the units within that territory(s) in accordance with their requests. Given the above discussion, the following hypotheses are presented:

H4: System-wide adaptation will have a stronger influence on operational performance in area development and area representative arrangements than incremental and master representation arrangements.

\subsection{Operating performance}

Common within the management literature, operational performance falls under the umbrella term of performance measurement or strategic performance measurement. The purpose of implementing performance measures is to monitor organisational progress and maintain organisational control (Nani et al. 1990). Monitoring and control of organisational standards enables organisations to pursue strategies which lead to the achievement of the goals and objectives of the organisation (Nani et al. 1990). However, today organisations are forced to become global enterprises as to remain competitive. 
Subsequently, this has encouraged companies to understand the key factors which drive organisational performance. As a result, organisations are forced to reassess their corporate vision and ensure that their performance measurement systems are aligned with their strategic goals and objectives (Eccles 1991; Kaplan 1983; Gregory 1993; Purbey et al. 2007).

The concept of strategic performance measurement was developed in response to criticism founded within the traditional performance measurement system (Kaplan, Norton 1993). The traditional perspective of performance measurement was narrowly defined, relying on financial measures to determine organisational performance (e.g. return on assets) (Bracker, Pearson 1986; Dess, Robinson 1984; Johnsen, McMahon 2005; Kaplan, Norton 1993; Watson 2002). However, Kaplan and Norton (1992) suggest that financial measures, whilst worthy of inclusion, are limited in depth and largely focus on past performance of the organisation, thereby, excluding current and future performance.

Popular within the management literature, the Balanced Scorecard developed by Kaplan and Norton (1992) is argued to most accurately explain performance. In particular, the Balance Scorecard accommodates past and current research by incorporating both financial and non-financial measures (i.e. operational measures) to determine strategic alignment (Hudson et al. 2001; Kaplan, Norton 1992). The purpose of the Balance Scorecard is to integrate a multi-faceted view of organisational performance (Atkinson, Brown 2001). The specific elements which to be explored in relation to each of the four dimensions of the Balance Scorecard from a franchising perspective: (1) financial perspective (i.e. franchisor revenue growth, franchisor gross revenue), (2) internal business process perspective (i.e. operations management, service and support, quality assurance systems and IT systems effectiveness), (3) franchisees' perspective (i.e. franchisee profitability, franchisee satisfaction, franchisee renewals) and, (4) learning and growth perspective (i.e. value of brand/franchise, research and development and information system capability). The proceeding discussion outlines the theoretical basis upon which the hypotheses of this study are proposed and shown in Figure 1.

\section{Research design}

The aim of this research was to examine the influence of the four strategic imperatives upon operational performance across the four multiple-unit franchising forms. Given the deficiencies present in the literature to date, a two-stage research design was used. Firstly, stage one included a mixed methods approach adopting both a qualitative and quantitative process. From a qualitative perspective, 16 convergent interviews (in-depth, unstructured) were conducted with franchisors from a mix of retail and service franchise systems within Australia. From the interviews, 53 items were generated for the development of the scale to be used in the final survey. These items were further validated by a panel of marketing and scale development experts resulting in 47 items measuring the four strategic imperatives, multiple-unit franchising and demographic variables (DeVellis 2003). Following this, a quantitative process was employed, whereby scale purification was achieved through statistical analysis. Secondly, stage two adopted a 


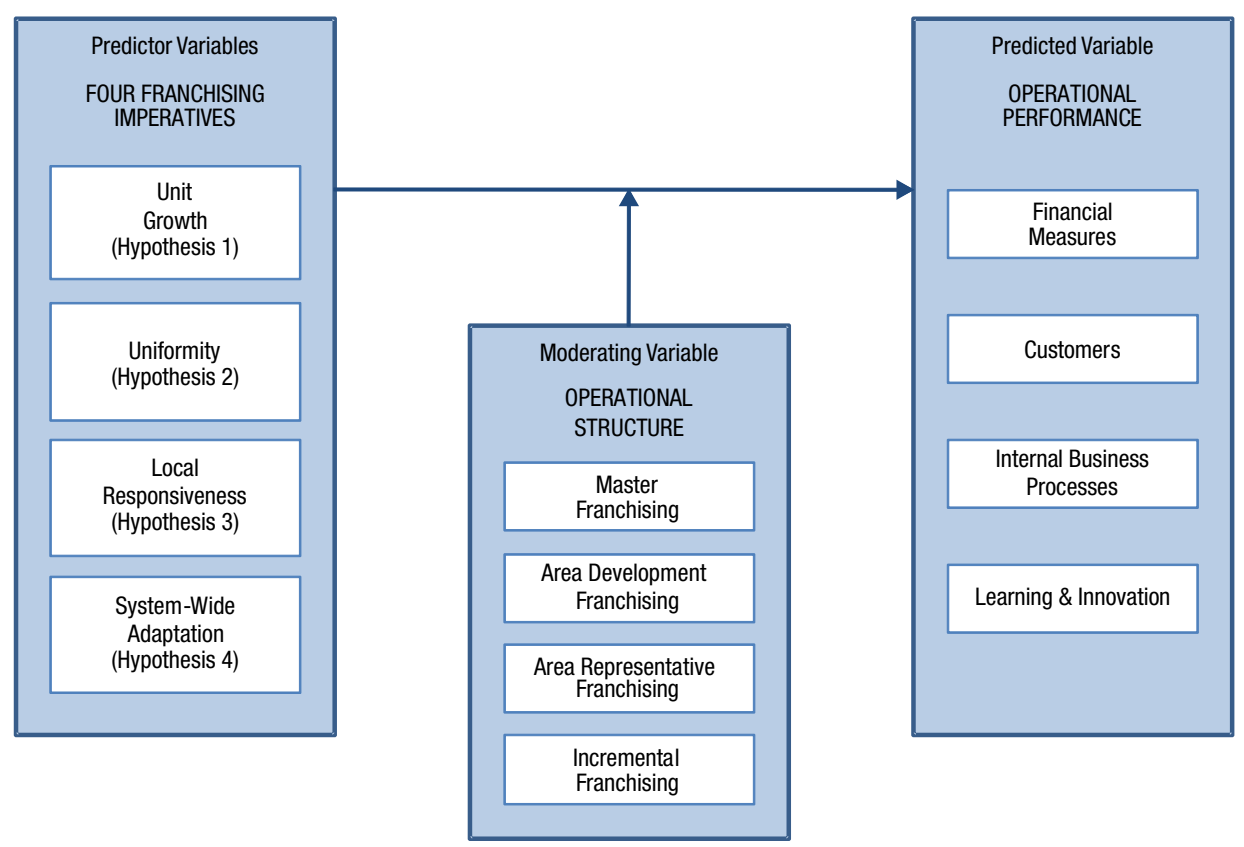

Fig. 1. Preliminary conceptual model of system operating performance in multiple-unit franchising

quantitative approach which involved three sequential steps. Firstly, the items generated from stage one were compiled for inclusion in a draft survey. Pilot testing enabled the refinement, deletion and addition of items to the survey and adaptation of the survey to the appropriate format. This resulted in the production of a final survey instrument which was administered in 2008 via email to 967 franchisors in Australia. The franchisors selected were emailed individually the survey link, purpose of the study and confidentiality agreement. The franchisors selected were obtained through a pre-existing database which was developed in conjunction with the peak franchising body of Australia (i.e. Franchise Council of Australia). This resulted in 347 completed surveys yielding a response rate of 27.9 per cent.

\subsection{Measures}

All questions on the survey were measured using a bipolar seven-point likert scale anchored on the words strong disagree (1) to strongly agree (7). Table 1 provides a summary of the items used to verify each construct including factor loadings and reliabilities for the respective items. Factor loadings range from .65 to .91 and reliabilities are all above the acceptable range of .60 as recommended by Jr. Hair et al. (1998).

Finally, the categorical measurement used to discriminate between groups (i.e., master franchising, area development franchising, area representative franchising and incremental franchising) asked respondents to rank the four franchising forms in order of preference. The following question is indicative of the question used in the survey. 
Table 1. Results of measurement model

\begin{tabular}{|c|c|c|c|}
\hline CONSTRUCT & SURVEY ITEMS & LOADINGS & ALPHA \\
\hline \multirow[t]{5}{*}{ Unit growth } & $\begin{array}{l}\text { Our number of franchisees within our system grows } \\
\text { each year. }\end{array}$ & .86 & .85 \\
\hline & $\begin{array}{l}\text { Our number of units within our system grows each } \\
\text { year. }\end{array}$ & .85 & \\
\hline & $\begin{array}{l}\text { In our system, we continuously have a large number } \\
\text { of franchise units opening. }\end{array}$ & .78 & \\
\hline & Unit growth is important in our strategic planning. & .75 & \\
\hline & $\begin{array}{l}\text { The ability to continually attract franchisees is impor- } \\
\text { tant in our strategic planning. }\end{array}$ & .73 & \\
\hline \multirow[t]{6}{*}{$\begin{array}{l}\text { System } \\
\text { Uniformity }\end{array}$} & $\begin{array}{l}\text { System uniformity is important in our franchise net- } \\
\text { work. }\end{array}$ & .86 & .87 \\
\hline & $\begin{array}{l}\text { The consistent appearance and presentation of the sys- } \\
\text { tem is important in our strategic planning (e.g., uni- } \\
\text { forms, colours, logo etc.). }\end{array}$ & .82 & \\
\hline & $\begin{array}{l}\text { Controlling quality across all units within the franchise } \\
\text { system is important in our network. }\end{array}$ & .82 & \\
\hline & $\begin{array}{l}\text { In our network, consistent replication of the brand and } \\
\text { system is important. }\end{array}$ & .87 & \\
\hline & $\begin{array}{l}\text { In our system it is important that individual units are } \\
\text { compliant with system standards. }\end{array}$ & .80 & \\
\hline & $\begin{array}{l}\text { All of our outlets in a region must offer uniform prod- } \\
\text { ucts/services. }\end{array}$ & .67 & \\
\hline \multirow[t]{4}{*}{$\begin{array}{l}\text { Local } \\
\text { Responsive }\end{array}$} & $\begin{array}{l}\text { Being responsive to local regions is important in our } \\
\text { franchise network. }\end{array}$ & .73 & .69 \\
\hline & $\begin{array}{l}\text { Constantly innovating franchisees, staff and customers } \\
\text { in our business products is important in the strategic } \\
\text { development of our franchise system. }\end{array}$ & .73 & \\
\hline & $\begin{array}{l}\text { In our system, we encourage franchisees to form alli- } \\
\text { ances with local businesses. }\end{array}$ & .65 & \\
\hline & $\begin{array}{l}\text { In our system, we train and develop franchisees to as- } \\
\text { sist them in meeting local market needs. }\end{array}$ & .79 & \\
\hline \multirow[t]{6}{*}{$\begin{array}{l}\text { System-Wide } \\
\text { Adaptation }\end{array}$} & $\begin{array}{l}\text { Regular communication between the franchisor or } \\
\text { head quarters and franchisees is important in our sys- } \\
\text { tem. }\end{array}$ & .76 & .85 \\
\hline & $\begin{array}{l}\text { We encourage new system-level learning and innova- } \\
\text { tion to improve current processes, which may result in } \\
\text { changes to the system. }\end{array}$ & .74 & \\
\hline & $\begin{array}{l}\text { Overtime, there has been a need to amend processes out- } \\
\text { lined in our system manuals (e.g., operations manual). }\end{array}$ & .74 & \\
\hline & $\begin{array}{l}\text { We encourage a good level of communication to ac- } \\
\text { commodate market forces. }\end{array}$ & .79 & \\
\hline & $\begin{array}{l}\text { We have operationalised good internal system process- } \\
\text { es which enable the facilitation and implementation } \\
\text { of new ideas more effectively throughout the system. }\end{array}$ & .75 & \\
\hline & $\begin{array}{l}\text { We believe that the franchisor has to invest both mon- } \\
\text { ey and resources to continuously improve the system } \\
\text { and keep up with the market. }\end{array}$ & .80 & \\
\hline
\end{tabular}


End of Table 1

\begin{tabular}{llcc}
\hline CONSTRUCT & \multicolumn{1}{c}{ SURVEY ITEMS } & LOADINGS & ALPHA \\
\hline $\begin{array}{l}\text { Operational } \\
\text { Perform }\end{array}$ & $\begin{array}{l}\text { Overall our franchisees are satisfied with our system } \\
\text { Overall the majority of our franchisees are operating } \\
\text { profitable. }\end{array}$ & .74 & .81 \\
& $\begin{array}{l}\text { Overall the franchise system is operating profitable } \\
\text { Our individual franchisees consistently report sales } \\
\text { growth each year. }\end{array}$ & .86 \\
& $\begin{array}{l}\text { Our franchise system consistently reports sales } \\
\text { growth each year. }\end{array}$ & .81 \\
& $\begin{array}{l}\text { Our franchisees continuously increase the volume of } \\
\text { products they sell each year. }\end{array}$ & .87 \\
& $\begin{array}{l}\text { The majority of our franchisees continuously exceed } \\
\text { projections. }\end{array}$ & .87 \\
& $\begin{array}{l}\text { The majority of our franchisees perform in excess of } \\
\text { our expectations. }\end{array}$ & .77 \\
\hline
\end{tabular}

Please indicate your preferred current multiple-unit franchising expansion strategy by ranking the following four alternatives from 1 (most preferred or used) to 4 (least preferred or not used).

a. Master franchisees:

b. Area Development Arrangements:

c. Area Representative Arrangements:

d. Sequential franchisees:

\subsection{Sample profile}

Demographic information reported on the survey indicated that the number of surveys gathered involved over 14 primary industries in the Australian franchise sector (refer to Table 2). In terms of the industry type, the majority of the sample (65\%) comprised of retail trade food, retail trade non-food and personal and other services categories of the franchise sector. The sample of franchise systems included in this study is representative of the Australia franchise sector which comprises of a mix of retail and service franchise systems enabling the results of the study to be reflective of the franchise sector of Australia.

In relation to gender the sample was predominately male (i.e. $78 \%$ ). Approximately half the sample involved franchise systems with fewer than 50 units and, similarly half the sample owned between one and five company-owned units and 30\% did not operate a companyowned unit at all. In addition, almost $40 \%$ of the organisations sampled began operating between 1990 and 1999. However, the results indicate that almost $40 \%$ of the organisations surveyed did not begin operating as a franchise organisation until the year 2000 to 2007.

In terms of multiple-unit ownership, almost $70 \%$ of franchise systems had fewer than 5 multiple-unit franchisees within their franchise organisations. While most franchise systems initially adopted incremental franchising (45.5\%) as their preferred expansionary method, only $35 \%$ continued with this strategy with some opting to change to master, area development and area representative arrangements. 
Table 2. Profile of respondents

\begin{tabular}{|c|c|c|}
\hline VARIABLE & CATEGORY & RESPONSE \\
\hline \multirow[t]{15}{*}{ Industry Category } & Retail trade non-food & $23 \%$ \\
\hline & Property and business services & $8 \%$ \\
\hline & Retail trade food & $27.1 \%$ \\
\hline & Personal and other services & $14.7 \%$ \\
\hline & Construction and trade services & $6.3 \%$ \\
\hline & Finance and Insurance & $2.9 \%$ \\
\hline & Accommodation, cafes and restaurants & $2 \%$ \\
\hline & Cultural and recreational services & $1.2 \%$ \\
\hline & Education & $2.9 \%$ \\
\hline & Communications/telecommunications & $1.7 \%$ \\
\hline & Manufacturing and printing & $0.6 \%$ \\
\hline & Wholesaling & $0.9 \%$ \\
\hline & Health and community services & $1.2 \%$ \\
\hline & Transport and storage & $0.9 \%$ \\
\hline & Unclassified & $5.5 \%$ \\
\hline \multirow[t]{2}{*}{ Gender of Franchisor } & Male & $78.4 \%$ \\
\hline & Female & $21.6 \%$ \\
\hline \multirow[t]{7}{*}{ Number of Units } & $0-50$ & $47.8 \%$ \\
\hline & $51-100$ & $20.5 \%$ \\
\hline & $101-150$ & $13.3 \%$ \\
\hline & $151-200$ & $6.3 \%$ \\
\hline & $201-250$ & $2.9 \%$ \\
\hline & $251-300$ & $2.6 \%$ \\
\hline & Above 300 & $6.6 \%$ \\
\hline \multirow[t]{5}{*}{ Year Began Operating } & 2000-2007 & $19 \%$ \\
\hline & 1990-1999 & $39 \%$ \\
\hline & 1980-1989 & $26.8 \%$ \\
\hline & 1970-1979 & $8.6 \%$ \\
\hline & Prior 1970 & $6.6 \%$ \\
\hline \multirow[t]{5}{*}{ Year Began Franchising } & $2000-2007$ & $39.5 \%$ \\
\hline & 1990-1999 & $38.6 \%$ \\
\hline & 1980-1989 & $15 \%$ \\
\hline & $1970-1979$ & $4 \%$ \\
\hline & Prior 1970 & $2.9 \%$ \\
\hline \multirow[t]{5}{*}{ Number of Franchised-Owned Units } & $0-50$ & $50.7 \%$ \\
\hline & $51-100$ & $19.6 \%$ \\
\hline & $101-150$ & $12.9 \%$ \\
\hline & $151-200$ & $6 \%$ \\
\hline & Over 200 & $10.8 \%$ \\
\hline
\end{tabular}




\section{Results}

\subsection{Preliminary analysis of scales}

Prior to the main analysis of the study, the scales used to measure the four strategic imperatives and operational performance underwent preliminary analysis. Initially, the data were visually inspected via tests of normality, skew and kurtosis through the representation of histograms. Following this, data was examined via Kaiser-Meyer Olkin and Bartlett's Test of Sphericity of which values of 0.60 for KMO and above was considered appropriate (Tabachnick, Fidell 2001). Likewise, values less that .05 were retained for Bartlett's Test of Sphericity (Hair et al. 1998). At this stage, items revealing correlations below .30 and above .90 were removed, as they were considered inappropriate for factor analysis (Hair et al. 1998; Tabachnick, Fidell 2001).

Exploratory factor analysis was conducted via principal components with varimax rotation based on the premise that all factor structures (i.e., unit growth, system uniformity, local responsiveness and system-wide adaptation) were expected to be one-dimensional. However, the dependent variable, operational performance, was expected to yield more than one factor given the nature of the measures (e.g., financial and non-financial measures). Thus, in this case, principal component factor analysis with direct oblimin rotation was used to compute the factors. Factor structures whereby items had factor loadings of less than .50 were removed (Comrey, Lee 1992). In addition, those items that had cross-loadings of greater than .40 were deleted from the data analysis ( $\mathrm{O}^{\prime} \mathrm{Cass}$ 2002). This resulted in the deletion of one item (system growth), one item (system uniformity), two items (local responsiveness), two items (system-wide adaptation) and six items (operational performance). The reliability of the remaining items of the scales was greater than the recommended level of 0.60 (Hair et al. 1998). Prior to conducting the analysis to address the hypotheses, composite variables were computed to test the structural relationships via Partial Least Sqaures (PLS). The means and resulting composite variables ranged from 5.12 to 6.25 and the standard deviations ranged from 0.76 to 1.37 (refer to Table 3). PLS is used in the analysis of structural equation modelling and is a multivariate technique that allows for the estimation and examination of paths between latent variables that are measured via multiple indicators.

Table 3. Preliminary analysis of scales

\begin{tabular}{|c|c|c|c|c|c|c|}
\hline VARIABLE & NO OF ITEMS & KMO & BARTLETTS & LOAD. & VAR. & ALPHA \\
\hline Unit Growth & 5 & .71 & .000 & $0.73-0.86$ & 63.33 & 0.85 \\
\hline System Uniformity & 6 & .88 & .000 & $0.67-0.87$ & 65.28 & 0.87 \\
\hline Local Responsiveness & 4 & .66 & .000 & $0.65-0.79$ & 52.61 & 0.69 \\
\hline System-Wide Adaptation & 6 & .86 & .000 & $0.74-0.80$ & 58.18 & 0.85 \\
\hline Operational Performance & 8 & .83 & .000 & $0.74-0.91$ & 69.78 & 0.88 \\
\hline COMPOSITE VARIABLES & MEAN & S.D & & & & \\
\hline Unit Growth & 5.12 & 1.37 & & & & \\
\hline System Uniformity & 6.25 & 0.81 & & & & \\
\hline Local Responsiveness & 5.80 & 0.89 & & & & \\
\hline System-Wide Adaptation & 5.94 & 0.76 & & & & \\
\hline Operational Performance & 5.41 & 0.88 & & & & \\
\hline
\end{tabular}




\subsection{Main analysis}

The measurement and structural parameters of our structural equation model were estimated via partial least squares (PLS). PLS is a general technique for estimating paths involving latent constructs indirectly observed by multiple indicators (Bontis 1998). PLS allows for three sets of relations: inner relations, outer relations and weight relations (Fornell, Cha 1994). The relationship between different latent constructs is specified by the inner relations and the relationship between observed variables and latent constructs are specified in the outer relations. The weight relations define the estimated latent constructs as weighted aggregates of the observed variables (Vandenbosch 1996). The conceptual core of PLS is a combination of principal components analysis which relates measures to constructs and path analysis which permits the construction of a system of paths. The hypothesised relationships between both measures and constructs and constructs and constructs are guided by theory. The objective in PLS is to maximise the explanation variance, thus the model is said to perform well if the $\mathrm{R}^{2}$ and the relationships among constructs are significant (Bontis 1998).

Furthermore, PLS calculates parameters using least squares estimations and a small sample size is not a deterrent to the generation of useful results. Moreover, PLS does not assume multivariate normality nor provides unbiased estimates (Tiessen, Linton 2000: 210). However, as sample size increases estimates quickly converge on best least unbiased estimators (BLUE) (Fornell, Bookstein 1982). PLS also accommodates both formative and reflective indicators, unlike AMOS and LISREL.

In addition, to test for differences in the proposed model across the four franchising arrangements, the data file was split into four groups. Data was collected with reference to master franchising, area development arrangements, area representative arrangements and incremental franchising. The results pertaining to master franchising yielded 82 cases; area development arrangements contained 69 cases; area representative arrangements contained 74 cases and; incremental franchising yielded 122 cases, hence the use in application of PLS given the small case sizes. Subsequently, each data file was analysed separately through PLS identifying the $\mathrm{R}^{2}$, significance of individual path coefficients and critical ratios (Fornell, Cha 1992).

\subsection{Model results: master franchising}

Table 4 shows the $\mathrm{R}^{2}$, path coefficients between the exogenous and endogenous variables and critical ratios. For the latent variable operational performance, the $\mathrm{R}^{2}$ exceeds the recommended level of .10 (Falk, Miller 1992) based on an estimation of the path significance associated with the predictor variables. In addition, the bootstrap critical ratios (Chin 1998) are acceptable for three variables (greater than 1.96) with the exception of local responsiveness, indicating that the hypothesised paths of unit growth, system uniformity and system-wide adaptation are supported; however, local responsiveness is rejected. Figure 2 provides an illustration of the PLS model results for master franchising.

\subsection{Model results: area development arrangements}

The PLS analysis for the data pertaining to area development arrangements providing the $\mathrm{R}^{2}$, path coefficients between the exogenous and endogenous variables and the 
critical ratios is presented in Table 4. For the latent variable operational performance, the results indicate that the $\mathrm{R}^{2}$ is greater than .10 as recommended by Falk and Miller (1992). This suggests that $38 \%$ of the variance is explained by unit growth, system uniformity, local responsiveness and system-wide adaptation. Furthermore, the bootstrap critical ratios (Chin 1998) are significant for one variable (greater than 1.96), being, system-wide adaptation. This indicates that the hypothesised path of system-wide adaptation is supported; however, unit growth, system uniformity and local responsiveness are rejected. Figure 2 provides an illustration of the PLS model results for area development arrangements.

\subsection{Model results: area representative arrangements}

Table 4 shows the $\mathrm{R}^{2}$, path coefficients between the exogenous and endogenous variables and the critical ratios. For the latent variable operational performance, the $\mathrm{R}^{2}$ is greater than .10 as recommended by Falk and Miller (1992), which indicates that $29 \%$ of the variance is explained by unit growth, system uniformity, local responsiveness and system-wide adaptation. Furthermore, the bootstrap critical ratios (Chin 1998) were significant for two of the variables (grater than 1.96) with the exception of system uniformity and local responsiveness. This indicates that the hypothesised paths of unit growth and system-wide adaptation are supported; however, system uniformity and local responsiveness are rejected. Figure 2 provides an illustration of the PLS model results for area representative arrangements.

Table 4. PLS results for the structural models

\begin{tabular}{llccc}
\hline PREDICTED VARIABLE & PREDICTOR VARIABLE & PATH & CRITICAL RATIO & $\mathrm{R}^{2}$ \\
\hline Master Franchising & $\mathrm{N}=82$ & & & \\
Operational Performance & Unit Growth & .22 & 2.04 & .44 \\
& System Uniformity & .27 & 1.97 & \\
& Local Responsiveness & $-.15^{*}$ & 1.81 & \\
& System-Wide Adaptation & .41 & 3.46 & \\
\hline Area Development & $\mathrm{N}=69$ & & & .38 \\
Operational Performance & Unit Growth & $.11^{*}$ & 0.77 & \\
& System Uniformity & $.09^{*}$ & 0.47 & .29 \\
& Local Responsiveness & $.03^{*}$ & 0.19 & \\
& System-Wide Adaptation & .45 & 1.96 & \\
\hline Area Representativeness & N =74 & & & \\
Operational Performance & Unit Growth & .31 & 2.61 & \\
& System Uniformity & $.13^{*}$ & 1.13 \\
& Local Responsiveness & $-.13^{*}$ & 0.94 \\
& System-Wide Adaptation & .33 & 2.38 & \\
\hline Incremental & N =122 & & & \\
Operational Performance & Unit Growth & .32 & 3.86 \\
& System Uniformity & .17 & 2.09 & \\
& Local Responsiveness & $.11^{*}$ & 1.17 \\
& System-Wide Adaptation & .30 & 2.49 & \\
\hline
\end{tabular}

Note: *Not Significant. 


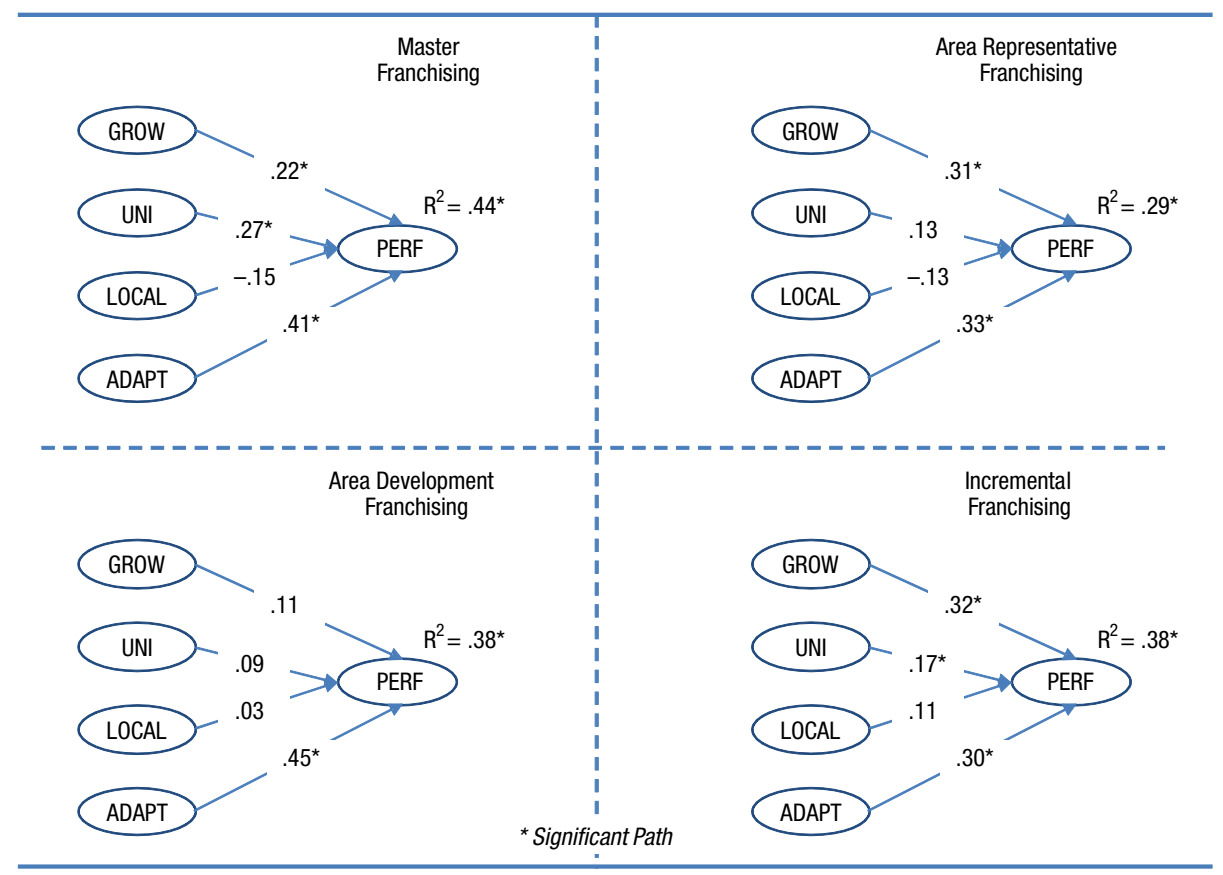

Fig. 2. Comparative results across structural models

\subsection{Model results: incremental franchising}

The results for the PLS analysis for the data concerning incremental franchising providing the $\mathrm{R}^{2}$, path coefficients between the exogenous and endogenous variables and the critical ratios is presented in Table 4. As recommended by Falk and Miller (1992), the $\mathrm{R}^{2}$ is greater than .10 (i.e. .38) which indicates that unit growth, system uniformity, local responsiveness and system-wide adaptation explain $38 \%$ of the variance. For the latent variable operational performance the bootstrap critical ratios (Chin 1998) are acceptable for three variables (greater than 1.96) with the exception of local responsiveness. This indicates that the hypothesised path of unit growth, system uniformity and system-wide adaptation are supported; however, local responsiveness is rejected. Figure 2 provides an illustration of the PLS model results for incremental franchising.

Table 5 provides an overview of the relationships between the four franchising imperatives and operational performance across the four franchising governance models and a summary of hypotheses results.

\section{Discussions}

The purpose of this research was to empirically validate the conceptual model proposed (refer to Figure I) and in doing so, determine the influence of the four strategic imperatives upon operational performance across the four multiple MUF forms. To begin, the following section will examine the influence of unit growth upon operational performance across the four multiple-unit organisational franchise structures. 
Table 5. Overview of hypotheses results

H1 Unit growth will have a stronger influence on operational performance in Not Supported area development arrangements, than master franchising, area representative and incremental franchising arrangements.

H2 Uniformity will have a stronger influence on operational performance in Not Supported area development and area representative arrangements than in incremental and master franchising.

H3 Local responsiveness will have a stronger influence on operational per- Not Supported formance in incremental franchising arrangements and master franchising than in area development and area representation arrangements.

H4 System-wide adaptation will have a stronger influence on operational Supported performance in area development and area representative arrangements than incremental and master representation arrangements.

\subsection{Unit growth}

Based on the results, hypothesis one was not supported (i.e., non-significant results for ADF). However, unit growth was found to have a significant positive relationship with operational performance across three multiple-unit franchise arrangements: master franchising, area representative arrangements and incremental franchising. Previous research confirms that master franchising has been linked to a decrease in operationally efficiency because there exists an intermediary (i.e. master) between the franchisor and franchisee (Kaufmann, Kim 1995). Often the franchisor is required to substitute operating efficiency for system growth (Kaufmann 1992; Kaufmann, Kim 1995). However, the findings of this study appear contrary to Kaufmann (1992) and Kaufmann and Kim's (1995) findings and suggest that growth of a franchise system does not occur at the expense of operational efficiency, rather, to achieve overall operational performance of the system.

Therefore, it appears that the findings of this research may confirm previous research. For example, Justis and Judd (1986) suggest that those franchise systems employing master franchise arrangements may have existing competencies in managing franchisees (for example, employ active channels of communication with franchisees, effective monitoring of franchisee behaviour). In this sense, the master franchisee will be able to curb the time and effort in recruiting, screening and training franchisees (i.e. subfranchisees). Therefore, the addition of resources (e.g. financial and managerial capital) enables the franchisor to sell territories to master franchisees more quickly and, consequently, expand into different geographic areas. Furthermore, the findings follow a similar line of thought advocated by Kaufmann and Dant (1996) whereby an increase in access to capital should enable multiple-unit organisational structures (such as master franchise arrangements) to expand at faster rates.

Contrary to the extant literature, AR are suggested to be the least likely governance form to achieve rapid system growth. However, whilst AR may not have a direct influence over the acquisition and subsequent growth of the franchise system, they may indirectly influence the performance of individual units. For example, ARs may encour- 
age active communication and monitoring between the franchisor, master franchisee and sub-franchisee. To this end, the AR may work closely with the master franchisee and sub-franchisee to ensure that they are operating in accordance with the franchise brand and operating procedures thus enabling units within the system to operate more efficiently (i.e. grow their bottom line). Therefore, the inclusion of area representative arrangements may indirectly influence the overall growth of the franchise system.

The results from this study are consistent with Bradach's (1995) findings which determined that incremental franchisees were a key source of unit growth. Often, there is less effort on the part of the franchisor as they rely on the knowledge obtained from the existing franchisee to be transferable to the new unit. For example, Kaufmann and Dant (1996; Barthelemy 2008) found that the acquisition of additional units occurs as franchisees have prior unit success and, therefore, have demonstrated both operational efficiency and productivity within an existing franchise unit. In particular, MUF such as incremental franchising may reduce the occurrence of franchisee shirking behaviour. Unlike hired managers, franchisees receive incentives (residual claims) and, therefore, franchisees are more likely to work towards greater operational efficiency as this may have a direct impact on their residual claims. For this reason, the franchisee's goals are closely aligned with the profit goals of the franchisor (Garg et al. 2005), thus encouraging the franchisee to achieve the goals of the franchisor.

This finding was contrary to the literature pertaining to area development arrangements and growth. Several prominent studies including Garg et al. (2005) and Kaufmann and Kim (1995) found that the key objective of area development arrangements is to enhance rapid system growth. However, this research found contradictory results and may more closely align with the original argument proposed by Kaufmann and Dant (1996) whom hypothesised that area development arrangements should reduce system growth rates (as a result of adverse selection costs). Effectively, the inability to manage and operate the system within the allocated time-frame may reduce the rate of growth of the assigned territory. Therefore, although the notion of an area developer is to formulise (manage and operate) a territory and to establish additional units promptly within that region, lack of experience may impede this from occurring, contradicting established arguments in relation to area development arrangements (Garg et al. 2005; Kaufmann, Kim 1995). In addition, the hired manager's behaviour may not fully align with the profit goals of the area developer. Consequently, this may limit the growth of units within the assigned territory because hired managers may be performing inefficiently.

\subsection{System uniformity}

System uniformity was found to have a significant positive relationship in influencing operational performance across two multiple-unit franchise arrangements: master franchising and incremental franchising disclaiming Hypotheses 2. Although the extant literature suggests that master franchisees are less likely to achieve system uniformity across units, the results appear inconsistent with previous research (Bradach 1995; Kaufmann, Kim 1995; Stern, El-Ansary 1988). The literature only suggests that master franchisees are to a lesser extent able to sustain system uniformity across independent units within their assigned territories, not that it is improbable (Kaufmann, Kim 1995). 
This may indicate that master franchisees are more proactive in their role than first assumed as they are responsible for providing initial and on-going training and support, the initiation of marketing programs and monitoring the adherence of operating, procedural and brand protection (Justis, Judd 1986; Kalnins 2005); all factors contributing to enhancing operational performance and, subsequently, sustaining system uniformity. Therefore, it appears that in an effort to ensure system uniformity (for example, quality control) the franchisor and master franchisee assume separate and distinct roles; the franchisor controls business operations, thereby, requiring master franchisees to serve as marketing agents (e.g. monitor the behaviour of franchisees).

Given that an incremental franchisee originates as a single unit franchisee, there may be a greater ability to maintain uniformity within their mini-chain as similar operational processes may be easily applied across a small number of units. Subsequently, the franchisor may be more inclined to engage in more active monitoring procedures as resource constraints attributed to monitoring (for example, financial, time and human) would be less than in large franchise systems. Moreover, Garg et al. (2005) suggests that incremental franchisees would be more likely to uphold system standards, as unit additions are dependent on the operational and managerial performance of the franchisee and, as such, is dependent on the franchisee complying with franchise system directives. Therefore, the deterioration of the brand through non-compliance with system standards may limit the franchisee from obtaining additional units (Bercovitz 2003).

The results suggest that system uniformity does not influence operational performance from an area development or area representative perspective. The results of this research may align with the original arguments proposed by Kaufmann (1992). Kaufmann (1992) suggested that franchisees operating more than one outlet would be unable to ensure the provision of service as closely as those franchisees monitoring a single unit. This suggests that unit performance is inversely related to the size of the mini-chain. Given that area developers are required to own and operate several outlets within the one territory, they may suffer from performance decay due to size (Bradach 1995; Weaven 2004) which would result in the area developer becoming an average performing operator. This, in turn, may impede the area developer from ensuring that system standards are consistent with those stipulated by the franchisor.

In relation to area representatives, the results appear to be consistent with previous research conducted by Lafontaine and Slade (1996), whom suggest that when monitoring costs are high (usually attributed to geographic dispersion of units) firms choose to monitor less frequently. This may explain why area representative arrangements in this study were found to be unlikely to influence the operational performance of franchise systems in relation to system uniformity. Therefore, the high costs attributed to monitoring units geographically distinct to the headquarters (i.e., franchisor), may indicate that compliance with system standards are less probable. In addition to monitoring franchisee behaviour, area representatives receive an agreed percentage of royalty contributions (Whittemore, Perry 1998) for recruiting potential franchisees. Therefore, the findings of this study suggest that area representatives should concentrate on the recruitment of franchisees rather than monitoring franchisee behaviour. 


\subsection{Local responsiveness}

The results suggest that local responsiveness does not influence operational performance across all four multiple-unit franchising arrangements, disconfirming Hypotheses 3. This is consistent with the research conducted by Bradach (1995), which found that multipleunit franchising was less effective in addressing the challenges associated with meeting local market conditions. In particular, prior research found that whilst multiple-unit franchising may facilitate system uniformity, as a consequence, it may limit local market responsiveness and innovation (Bradach 1998; Ingram 1996).

In relation to master franchisees, the results may suggest that master franchising often entails the application of an additional level of management (i.e. sub-franchisor) and, therefore, it may be less likely that the master franchisee observes all independent franchise units within their assigned territory at the individual store level, rather, at a 'middle' management level overseeing the assigned territory holistically. Although, previous studies (e.g. Minkler 1992) argue that local markets rely on local level decision makers who understand local market tastes and preferences and, therefore, have the knowledge to be locally responsive; this may not be so from a master franchising perspective. That is, master franchisees operating franchised units that attempt to develop processes which accommodate local market demands and local idiosyncrasies may provide little value to those operating in other areas within the territory.

In relation to area development franchising, the results support Bradach's (1995) findings suggesting that because hired managers are likely to move positions more frequently than would owner-operators, they would be less likely to acquire knowledge and experience of local market operations. For example, Darr et al. (1995) found that managerial turnover accounted for more than 50 per cent in their study exploring productivity in franchise organisations. In addition, hired managers may shirk (i.e. reduce effort) the system as they are not residual claimants and, subsequently, receive fixed salaries (Garg et al. 2005; Lafontaine 1992). Therefore, hired managers are less inclined to actively pursue local market opportunities (e.g. networking with local businesses) on behalf of the owner-operator (e.g. area developer).

From an area representative perspective, the results suggest that the primary role of an area representative is to oversee an assigned territory(s) on behalf of the franchisor. In particular, this requires the area representative to monitor the behaviour of franchisees and ensure that franchisees are complying with the franchise concept and format. In addition, an area representative is also responsible for soliciting prospective franchisees (Whittemore, Perry 1998). On this basis, an area representative's function is to monitor and recruit potential franchisees, their role (i.e. function) does not require them to ensure that franchisees are responding to local market needs (e.g. networking, modifying the product concept), hence, being locally responsive.

In relation to incremental franchising, the results may support the findings of Bradach (1995), who suggests that the size of the franchisee may influence the ability of the franchisee to be locally responsive. Bradach (1995) argues that franchise systems that empower their franchisees to obtain local market knowledge are more effective in re- 
sponding to local market needs (Jensen, Meckling 1976). However, Bradach (1995) also suggests that as single-unit franchisees grow in size (i.e. become incremental franchisees), their ability to respond effectively to the local market decreases. In addition, given that an incremental franchisee began as a single-unit operator, their initial intentions when entering into the contractual arrangement with the franchisor may not include the addition of further units. Therefore, if the single-unit franchisee (in agreement with the franchisor) is granted the right to additional units, they may lack the necessary expertise to operate multiple-units. In support of this contention, Weaven and Frazer (2007) and Kaufmann (1990), found that in certain franchise systems multiple-unit operators had a lack of local market knowledge which resulted in performance decay in the franchisee-owned subsystem.

\subsection{System-wide adaptation}

Our results suggest that system-wide adaptation does influence operational performance across all four MUF arrangements. Previous research suggests that for a franchise system to be sustainable (i.e. grow and survive) it must be able to evolve with changes that occur in the marketplace (Shane 2001). Although, adaptations can become difficult especially for those systems which have many geographically dispersed units (Bradach 1997), multiple-unit operators may be more willing to implement system changes because they possess similar management issues to that of a franchisor (Dant, Gundlach 1998). For example, from a multiple-unit perspective both a master franchisee and area developer operate as a sub-franchisor; however, they are responsible for overseeing (for example, recruiting, monitoring etc.) a territorial region as opposed to the entire franchise system. Similarly, the role of an area representative is to monitor the behaviour and performance of franchisees within an assigned geographic region; thereby, mimicking the role of a franchisor on a smaller scale. In relation to incremental franchisees, the granting of additional units may indicate that as their units grow in number, they adopt a more managerially-oriented role in order to govern additional units in their subsystem.

Moreover, Dant et al. (1995) suggest that a mutual exchange of information can enhance the longevity of the franchisor-franchisee relationship and influence the service quality of the system. This is in support of earlier research suggesting that effective communication can influence the performance of the organisation (Snyder, Morris 1984). For example, the role of an area representative is to act on behalf of the franchisor and maintain regular communication with franchisees, including outlet visits (Bradach 1997; Dant, Nasr 1998).

Subsequently, regular communication and contact by area representatives may ensure that the generation of new ideas or franchisee concerns are regularly attended to ensuring a proactive and open relationship between the franchisor and franchisee. As such, the need for changes (based on the requisite of the franchisor) may be more likely because franchisees are likely to see the franchisor working on behalf of their interests. Furthermore, knowledge transfer is essential across multiple-unit operations to enhance system-wide improvements (Barthelemy 2008; Sorenson, Sorenson 2001). In support of this, Sen (2001) suggests that this is apparent in the master franchise arrangement as 
master franchisees have access to downstream information (from franchisees). As such, master franchisees are able to observe independent franchisees in their territory and, where necessary, take timely action. Therefore, because they are within close proximity to the franchisees, master franchisees can supervise more effectively (Sen 2001) and ensure system compliance (including system changes).

Furthermore, Bradach (1995) suggests that franchisees are more willing to implement ideas in which they have had a vested input. In other words, those franchisors that actively engage with franchisees to solicit their expertise and knowledge of the product in their local market are more likely to comply with adaptations when those ideas are considered self-generated. Generally, the findings of this study substantiate the research conducted by Bradach (1995). For example, the purpose of granting an additional unit to an incremental franchisee is, in part, based on their success (i.e. performance) attributed to their knowledge and experience within their local market. Therefore, should franchisors implement adaptations that align with local markets (providing these are adaptable across regions) multiple-unit operators such as incremental franchisees would be more willing to adhere to system changes.

\subsection{Summary of the findings}

In summary, the findings suggest that unit growth is likely to influence the operational performance of master, area representative and incremental franchising arrangements. Similar findings were found in reference to system uniformity whereby uniformity was likely to influence operational performance across master and incremental franchising arrangements however not in reference to area development or area representative arrangements. Interestingly, local responsiveness was unlikely to influence operational performance across all four franchising arrangements (i.e. master, area development, area representative and incremental franchising). However, unlike local responsiveness, system-wide adaptation was likely to influence operational performance in relation to all four franchising arrangements (i.e. master, area development, area representative and incremental franchising). Table 6 provides a summary of the findings from the results of the current study.

Table 6. Overview of hypotheses results

\begin{tabular}{lcccc}
\hline & Master & Area Development & Area Represent. & Incremental \\
\hline Unit Growth & $\sqrt{ }$ & $*$ & $\sqrt{ }$ & $\sqrt{ }$ \\
\hline System Uniformity & $\sqrt{ }$ & $*$ & $*$ & $\sqrt{ }$ \\
\hline Local Responsiveness & $*$ & $*$ & $*$ & $*$ \\
\hline System-Wide Adaptation & $\sqrt{ }$ & $\sqrt{ }$ & $\sqrt{ }$ \\
\hline
\end{tabular}

Notes: $\sqrt{ }=$ Significant Relationship with Performance $*=$ Non-Significant Relationship with Performance. 


\section{Implications, limitations and future research}

\subsection{Theoretical implications}

This research affirms that multiple-unit franchising is a pervasive and preferred form of franchise expansion in Australia (see Frazer et al. 2008); a sentiment reiterated in past research overseas (Hussain, Windsperger 2010). Moreover, the findings provide insight into the common multiple-unit organisational structures employed by Australian franchisors. However, whilst multiple-unit franchising is becoming an increasingly popular expansion strategy, there has been limited research on what mode of multipleunit franchising expansionary strategy is more effective in terms of realising the four franchising imperatives. This is particularly important as previous studies (e.g. Bradach 1995; Garg et al. 2005) suggest that the four franchising imperatives of unit growth, system uniformity, local responsiveness and system-wide adaptation are fundamental to the operational efficiency and sustainability of franchise systems. Subsequently, by empirically examining the four franchising imperatives, this study has provided valid and reliable measures in relation to the four franchising imperatives (which can be utilised in future research).

Furthermore, these results extend current multiple-unit franchising research conducted in the United States (Bradach 1995; Garg et al. 2005) finding that the four franchising imperatives are able to determine which multiple-unit organisational form is more effective in achieving system-level operational performance. Specifically, unit growth was found to enhance operational performance across three multiple-unit organisational forms (i.e. master franchising, area representative franchising and incremental franchising) confirming the original arguments first proposed by Bradach (1995). Furthermore, this research extends Bradach's (1996) studies through providing additional insight into the importance of unit growth through empirically testing each multiple-unit mode (e.g. master franchising) to identify system (operational) performance.

In addition, the findings suggest that system uniformity does increase the operational performance for those franchise systems which adopt master franchising and incremental franchising multiple-unit organisational forms, a finding contrary to past MUF research (Garg et al. 2005). Although, previous studies have linked multiple-unit expansion with system uniformity (e.g. Bradach 1995; Garg et al. 2005), the inconsistent findings between this study and Garg et al. (2005) (to the best of our knowledge the only known existing additional study to examine system uniformity and modes of multipleunit organisational forms) may be a result of the factors governing franchising choice in Australia. For example, Frazer et al. (2008) identify that on average Australian franchise systems occupy 22 units which may substantiate the limited use of area development and area representative franchising as both arrangements (in terms of their function) are often utilised in systems which have highly dispersed units. This suggests that franchise sector and firm-level differences (e.g. age and size) between countries may influence the use and successful management of different modes of multiple-unit structures.

Our results also infer that not all four franchising imperatives are fundamental to the operational efficiency of different multiple-unit organisational structures. In particular, 
we found that across all multiple-unit organisational forms, local responsiveness yielded a non-significant finding. Suggesting that whilst local responsiveness is considered an important factor in the operational efficiency of franchise firms (Bradach 1995) it may well be limited to the single-unit franchise form (Bradach 1995). Therefore, the applicability of local responsiveness from a multiple-unit perspective appears to be an extraneous factor and, as such, its inclusion as one of the four franchising imperatives may be redundant.

However, the results do affirm the importance of growing the franchise system through new products and innovations. More importantly, the findings suggest that the application of system-wide changes is an important ingredient of franchise system operational performance across all multiple-unit organisational forms. On this basis system-wide changes need to be transferable and actionable across all units so as to enhance the operational performance of the overall franchise system. This is a particularly important finding as there have been very few studies that have examined the influence of system-wide changes in franchising, generally (e.g. Sorenson, Sorenson 2001) or from a multiple-unit franchising perspective, specifically (e.g. Bradach 1995).

\subsection{Managerial implications}

In addition to the theoretical implications presented above, this research also presents several implications for management practice. Although several relationships in the conceptual model were confirmed, the lack of confirmation in relation to other additional areas of the model suggests that managers may be influenced by other factors in determining operational performance in their systems, than has been previously identified in the literature (Bradach 1995; Garg et al. 2005). Although the four franchising imperatives proposed by Bradach (1995) did confirm or provide insight into how and which of the four franchising imperatives can influence operational performance across the four key multiple-unit organisational structures, local responsiveness was found to be non-significant across all MUF arrangements. Such a result suggests that the franchisors or franchise concepts that are highly dependent upon local market initiatives to remain competitive and survive, should re-evaluate the relative merits associated with adopting an MUF growth strategy.

Although viewed as a conceptually unsound alternative to traditional SUF models, MUF has a myriad of associated advantages (Lafontaine 2004). In particular MUF offers franchise systems scale economies (e.g. Grünhagen, Mittelstaedt 2002, 2005), rapid expansion (e.g. Combs, Castrogiovanni 1994), greater input into decision-making (e.g. Grünhagen, Mittelstaedt 2002) and a reduction of monitoring due to franchisees being residual claimants of the profits derived from their outlets (e.g. Norton 1988; Fama, Jensen 1983). Although not all factors comprising of the conceptual model were confirmed, this research may assist franchisors in providing some preliminary answers as to which multiple-unit expansionary strategy to adopt. The general implication here is that the findings of this research could be used to inform managers (and franchisors) of which multiple-unit organisational form is more effective in the achievement of certain performance outcomes (e.g. growth, system-wide adaptation). In this research master franchising was found to more likely influence performance outcomes of unit growth, 
system uniformity and system-wide adaptation. Knowledge of the relative merits of each MUF form in terms of expected performance outcomes should assist franchisors (and Head Office management) in determining the most appropriate MUF strategy within the context of the system brand and preferred service delivery models (Weaven et al. 2009).

Furthermore, some franchisors may utilise ad hoc methods of system expansion in an effort to grow the number of units within a system as their reparation is directly linked to sales growth. In addition, multiple-unit franchising is more common in mature franchise systems which may be attributed to the fact that mature systems offer less risk in terms of this form of expansion (for example, system success due to longevity). A1though this research hypothesised that the four franchising imperatives may influence the operational performance (for example, success/ sustainability) of franchise systems across different multiple-unit organisational forms, the true reasons why multiple-unit arrangements exists may be due to the franchisor's yearning for growth. As such, franchisors may adopt multiple-unit arrangements such as master franchising purely because it is a common method employed by franchise systems within Australia and other nations, although their understanding of the real function and benefits of this expansionary strategy may be somewhat limited. However, given the increasing level of disputation in systems that occupy multiple-unit ownership arrangements (Weaven, Frazer 2003, 2006) this strategy may prove to be non-sustaining. Moreover, franchisors may adopt different multiple-unit organisational forms because they lack suitable franchisee candidates, although their operational and structural components of the business may not be prepared to engage in multiple-unit ownership.

\subsection{Limitations}

This study presents three specific limitations, notably, the data-collection method, the generalisability of the findings based on an Australian sample and managerial orientation. Firstly, the use of surveys as the data collection method raised some concerns over possible measurement error. However, as presented in the results section, the scales all reported acceptable reliabilities and acceptable factor structures. Secondly, the sample of franchisor respondents was drawn exclusively from Australia which may inhibit the generalisability of results. For example, the results may differ if the sample population was based on transitional economies (e.g. Eastern Europe). However, as suggested by Alon and McKee (1999) and Frazer (2000) Australian franchise systems occupy a mature level of franchising, similar to other localities in which franchising is commonly adopted as an retail form (e.g. the USA, Europe) (Alon, McKee 1999; Frazer 2000). Finally, limitations may surround the differences in managerial orientation, which may limit the predictive application of this study to all franchise systems. In this sense, many of the arguments proposed may be dependent on the franchisors willingness and tendency to adopt multiple-unit franchising expansionary strategies. Previous research has found that franchise systems and managerial orientation may change over time (e.g. Oxenfeldt, Kelly 1969). Therefore, the original motivations revealing why franchisors choose to engage in MUF may become increasingly vague. As such, the inability of franchisors to accurately identify and justify their prior decision-making may limit the validity of the results (Dant 1995). 


\subsection{Future research}

The limitations of this study suggest that there is considerable scope for franchising scholars to conduct further research in the area of MUF. This study identifies four specific areas for the direction of future research: moderating factors, validation of scale instrument, geographical locations and franchisee/customer perspective. Firstly, it is suggested that an exploratory study be conducted to determine moderating factors between the four franchising imperatives and operational performance. In particular, moderating variables which could potentially influence operational performance in relation to the four franchising imperatives could include system maturity, timing of the system to employ multiple-unit ownership arrangements and the size and contiguity (Kalnins, Lafontaine 2004; Yin 2006) of the mini-chain. For example, those systems which are within close geographic proximity may be more likely to realise unit growth faster than those mini-chains geographically distant to one another. Secondly, given that this study investigated the influence of the four franchising imperatives in relation to operational performance across different multiple-unit organisational structures, future research could further confirm the (developed) scale instrument. By doing so, this would provide greater validation (and reliability) of the items found to represent each of the five constructs (i.e. franchising imperatives and operational performance) and, thereby, provide a more psychometrically sound survey instrument to measure system performance in multiple-unit franchising. Thirdly, to validate the findings of this study, further exploration of system performance in relation to multiple-unit franchising should be examined within different geographical locations (e.g. Easter Europe, China etc.) to confirm the generalizability of the results of this study. Finally, the purpose of this study was to examine system performance in multiple-unit franchising from the franchisors perspective. It would be interesting to realise whether the results of this study would be different if taken from the perspectives of the franchisee or customer.

\section{References}

Alon, I.; McKee, D. 1999. Toward a macro-environmental model of international Franchising, Multinational Business Review 7(1): 76-82.

Amato, S.; Esposito, V.; Tenenhaus, M. 2004. A global goodness-of-fit index for PLS structural equation modelling, in Oral Communication to PLS Club, March 24, 2004, HEC School of Management, France.

Anderson, J. C.; Gerbing, D. W. 1988. Structural equation modelling in practice: a review and recommended two-step approach, Psychology Bulletin 103(3): 411-423.

http://dx.doi.org/10.1037/0033-2909.103.3.411

Atkinson. H.; Brown, J. B. 2001. Rethinking performance measures: assessing progress in UK hotels, International Journal of Contemporary Hospitality Management 13(3): 128-135.

Bagozzi, R. P.; Heatherton, T. F. 1994. A general approach to representing multifaceted personality constructs: application to state self-esteem, Structural Equation Modeling 1(January): 35-67. http://dx.doi.org/10.1080/10705519409539961

Bagozzi, R. P.; Yi, Y. 1988. On the evaluation of structural equation models, Journal of the Academy of Marketing Science 16(Spring): 74-94. http://dx.doi.org/10.1007/BF02723327

Barthelemy, J. 2008. Opportunism, knowledge and the performance of franchise chains, Strategic Management Journal 29: 1451-1463. http://dx.doi.org/10.1002/smj.719 
Bauldauf, A.; Cravens, K. S.; Diamantopoulos, A.; Zeugner-Roth, P. S. 2009. The impact of product-country image and marketing efforts on retailer-perceived brand equity: an empirical analysis, Journal of Retailing 85(December): 437-452.

Bercovitz, J. E. L. 2003. The option to expand: the use of multi-unit opportunities to support selfenforcement agreements in franchise relationships, in J. Windsperger (Ed.). The first international conference on economics and management of networks, 2003, Vienna, Austria.

Bodipo-Memba, A.; Lee, L. 1997. Business brief: boston chicken posts disappointing net, considers replacing franchisee system, Wall Street Journal (Eastern ed.) 31 October: 1.

Bontis, N. 1998. Intellectual capital: an exploratory study that develops measures and models, Management Decision 36(2): 63-76. http://dx.doi.org/10.1108/00251749810204142

Bracker, J. S.; Pearson, J. N. 1986. Planning and financial performance of small, mature firms, Strategic Management Journal 7: 503-522. http://dx.doi.org/10.1002/smj.4250070603

Bradach, J. L. 1992. The organization and management if chains: owning, franchising and the plural form. Unpublished doctoral thesis, Harvard University.

Bradach, J. L. 1995. Chains within chains: the role of multiple-unit franchisees, Journal of Marketing Channels 4(1/2): 65-81. http://dx.doi.org/10.1300/J049v04n01_05

Bradach, J. L. 1997. Using the plural form in the management of restaurant chains, Administrative Science Quarterly 42(2): 276-303. http://dx.doi.org/10.2307/2393921

Bradach, J. L. 1998. Franchise organizations. Boston, MA: Harvard Business School Press.

Brickley. J.; Dark, F. 1987. The choice of organizational form, Journal of Financial Economics 18(2): 401-20.

British Franchise Association/Natwest. 2006. Franchise survey. Oxford: BFA.

Caves, R. E.; Murphy, II. W. F. 1976. Franchising, firms, markets and intangible assets, Southern Economic Journal 42: 572-586. http://dx.doi.org/10.2307/1056250

Cheng, J. M. S.; Lin, J. Y. C.; Tu, J. H. J., et al. 2007. Toward a strategic model of international franchise system development, Journal of Marketing Channels 14(4): 65-83.

http://dx.doi.org/10.1300/J049v14n04_04

Chin, W. 1998. The partial least squares approach for structural equation modelling, in G. A. Marcoulides (Ed.). Modern methods for business research. Mahwah, NJ: Lawrence Erlbaum Associates, 295-336.

Chow, L.; Frazer, L. 2003. Servicing customers directly: mobile franchising arrangements in Australia, European Journal of Marketing 37(3/4): 594-613.

http://dx.doi.org/10.1108/03090560310459104

Cohen, J. 1988. Statistical power analyses for the behavioural sciences. 2nd ed. Hillside, NJ: Lawrence Erlbaum Associates.

Combs, J. G.; Castrogiovanni, G. J. 1994. Franchisor strategy: a proposed model and empirical test of franchise versus company ownership, Journal of Small Business Management 32(2): $37-48$.

Combs, J. G.; Ketchen, D. J. 2003. Why do firms use franchising as an entrepreneurial strategy?, Journal of Management 29: 43-65.

Comrey, A. L.; Lee, H. B. 1992. A first course in factor analysis. 2nd ed. New Jersey: Lawrence Relbaum Associates, Publishers.

Dant, R. P. 1995. Motivation for franchising: rhetoric versus reality, International Small Business Journal 14(1): 10-32. http://dx.doi.org/10.1177/0266242695141001

Dant, R. P.; Gundlach, G. T. 1998. The challenge of autonomy and dependence in franchised channels of distribution, Journal of Business Venturing 14(1): 35-67.

http://dx.doi.org/10.1016/S0883-9026(97)00096-7 
Dant, R. P.; Kacker, M.; Couglan, A. T.; Emerson, J. 2007. A cointergration analysis of the correlates of performance, in G. Cliquet, G. Hendrikse, M. Tuunanen, J. Windsperger (Eds.). Franchised channels in the economics and management of networks: franchising networks; cooperatives, joint ventures and alliances. New York: Springer Publishing, 168-189.

Dant, R. P.; Li, Z.; Wortzel, L. 1995. Linking relationship quality and service quality in franchise systems: model and measurement, in R. A. Dant, P. J. Kaufmann (Eds.). Franchising: contemporary issues and research. New York: The Hawthorn Press, 103-124.

Dant, R. P.; Nasr, N. I. 1998. Control techniques and upward flow of information in franchising in distant markets: conceptualization and preliminary evidence, Journal of Business Venturing 13(1): 3-28. http://dx.doi.org/10.1016/S0883-9026(97)00040-2

Dant, R. P.; Perrigot, R.; Cliquet, G. 2008. A cross cultural comparison of the plural form in franchise networks: USA, France and Brazil, Journal of Small Business Management 46(2): 286-311. http://dx.doi.org/10.1111/j.1540-627X.2008.00244.x

Dant, R. P.; Weaven, S. K.; Herington, C. 2008. Franchisee personality traits, gender and multiunit structure as predictors of franchisee-franchisor relationship strength, in G. Cliquet (Ed.). The $22^{\text {nd }}$ Annual International Society of Franchising Conference, 20-21 June, 2008, St. Marlo, France.

Dant, R. P.; Weaven, S. K.; Lupuka, B.; Baker, J.; Jeon, H. 2009. An introspective examination of single versus multi-unit franchisees in M. Grünhagen (Ed.). The $23^{\text {rd }}$ Annual International Society of Franchising Conference, February 12-14, San Diego, USA.

Darr, E. D.; Argote, L.; Epple, D. 1995. The acquisition, transfer and depreciation of knowledge in service organizations: Productivity in franchises, Management Science 41(11): 1750-1762. http://dx.doi.org/10.1287/mnsc.41.11.1750

Dess, G. G.; Robinson, R. B. 1984. Measuring organizational performance in the absence of objective measures: The case of the privately-held firm and conglomerate business unit, Strategic Management Journal 5: 265-273. http://dx.doi.org/10.1002/smj.4250050306

DeVellis, R. F. 2003. Scale development: theory and applications. 2nd ed. Thousand Oaks: Sage Publications.

Eccles, R. 1991. The performance management manifesto, Harvard Business Review JanuaryFebruary: 131-137.

Falk, R. F.; Miller, N. B. 1992. A primer for soft modelling. Akron, OH: University of Akron Press.

Fama, E. F.; Jensen, M. C. 1983. Separation of ownership and control, Journal of Law and Economics 26: 301-325. http://dx.doi.org/10.1086/467037

Frazer, L. 2000. Assessing franchising sector maturity: Australian evidence, Australasian Marketing Journal 8(2): 33-46. http://dx.doi.org/10.1016/S1441-3582(00)70189-3

Fornell, C.; Cha, C. 1992. Partial least squares, Working paper. Graduate School of Business, The University of Michigan, Michigan.

Fornell, C.; Bookstein, F. L. 1982. Two structural equation models: LISREL and PLS applied to consumer-exit voice theory, Journal of Marketing Research 19(November): 440-452.

http://dx.doi.org/10.2307/3151718

Fornell, C.; Larcker, D. F. 1981. Evaluating structural equation models with unobservable variables and measurement error, Journal of Marketing Research 18(February): 39-50. http://dx.doi. org/10.2307/3151312

Frazer, L.; Weaven, S.; Wright, O. 2006. Franchising Australia 2006. Brisbane: Griffith University/Franchise Council of Australia.

Frazer, L.; Weaven, S.; Wright, O. 2008. Franchising Australia 2008. Brisbane: Griffith University/Franchise Council of Australia. 
Frazer, L.; Weaven, S; Bodey, K. 2010. Franchising Australia 2010. Brisbane: Griffith University/Franchise Council of Australia.

Garg, V. K.; Rasheed, A. A.; Priem, R. L. 2005. Explaining franchisors' choices of organization forms within franchise systems, Strategic Organization 3(2): 185-217.

http://dx.doi.org/10.1177/1476127005052210

Gregory, M. 1993. Integrated performance measurement: a review of current practice and emerging trends, International Journal of Production Economics 30-31: 281-296.

http://dx.doi.org/10.1016/0925-5273(93)90099-7

Gómez, R. S.; González, I. S.; Vázquez, L. 2010. Multi-unit versus single-unit franchising: assessing why franchisors use different ownership strategies, The Services Industries Journal 20(3): 463-476. http://dx.doi.org/10.1080/02642060802252027

Grünhagen, M.; Dorsch, M. J. 2003. Does the franchisor provide value to franchisees? Past, current and future value assessments of two franchisee types, Journal of Small Business Management 41(4): 207-225. http://dx.doi.org/10.1111/1540-627X.00088

Grünhagen, M.; Mittelstaedt, R. A. 2000. Single-unit vs multiple-unit franchising: history, typology, and the franchisee perspective, in A. Paswan (Ed.). The14th International Society of Franchising Conference, 19-20 February, 2000, San Diego, CA.

Grünhagen, M.; Mittelstaedt, R. A. 2002. Is bigger better: the anticipation of scale efficiencies and decision participation as motivations for aspiring multiple-unit franchisees, International Journal of Entrepreneurial Behaviour \& Research 8(3): 188-200.

http://dx.doi.org/10.1108/13552550210436512

Grünhagen, M.; Mittelstaedt, R. A. 2005. Entrepreneurs or investors: do multiple-unit franchisees have different philosophical orientations?, Journal of Small Business Management 43(3): $207-$ 225. http://dx.doi.org/10.1111/j.1540-627X.2005.00134.x

Hair, Jr. J. F.; Anderson, R. E.; Tatham, R. L. 1998. Multivariate data analysis. 5th ed. Upper Saddle River, New Jersey: Prentice Hall.

Hudson, M.; Smart, A.; Bourne, M. 2001. Theory and practice in SME performance measurement systems, International Journal of Operations \& Production Management 21(8): 1096-1115. http://dx.doi.org/10.1108/EUM0000000005587

Hussain, D.; Windsperger, J. 2010. Multi-unit ownership strategy in franchising: development of an intergrative model, Journal of Marketing Channels 17(1): 3-31.

http://dx.doi.org/10.1080/10466690903435752

Ingram, P. 1996. Organizational form as a solution to the problem of credible commitment: the evolution of naming strategies among U.S hotel chains 1898-1980, Strategic Management Journal 17(Special Issue): 85-98.

Jensen, M. C.; Meckling, W. H. 1976. Theory of the firm: managerial behaviour, agency costs and ownership structure, Journal of Financial Economics 3: 305-360.

http://dx.doi.org/10.1016/0304-405X(76)90026-X

Johnsen, G. J.; McMahon, R. G. 2005. Owner-manager gender, financial performance and business growth amongst SMEs from Australia's business longitudinal survey, International Small Business Journal 23(2): 115-142. http://dx.doi.org/10.1177/0266242605050509

Justis, R. T.; Judd, R. J. 1986. Master franchising: a new look, Journal of Small Business Management 24(3): 16-21.

Kalnins, A. 2005. Overestimation and venture survival: an empirical analysis in international master franchising ventures, Journal of Economics and Management Strategy 14(4): 933-953. http://dx.doi.org/10.1111/j.1530-9134.2005.00088.x

Kalnins, A.; Lafontaine, F. 1999. Incentive and strategic motives for vertical separation: evidence from location patterns in the Texan fast food industry, Working paper. University of Michigan, Michigan. 
Kalnins, A.; Lafontaine, F. 2004. Multiple-unit ownership in franchising: evidence from the fastfood industry in Texas, The RAND Journal of Economics 35(4): 747-761.

http://dx.doi.org/10.2307/1593771

Kaplan, R. 1983. Measuring manufacturing performance: a new challenge for managerial accounting research, The Accounting Review 18(4): 686-705.

Kaplan, R.; Norton, D. 1992. The balance scorecard: the measures that drive performance, Harvard Business Review January-February: 71-79.

Kaplan, R.; Norton, D. 1993. Putting the balance scorecard to work, Harvard Business Review, September-October: 147-182.

Kaufmann, P. J. 1990. A comparison of various methods of franchise expansion, in R. Robicheaux (Ed.). The 4th Conference of the Society of Franchising, Franchising: Evolution in the Midst of Change, 22-24 February, 1990, Scottsdale, Arizona, 1-25.

Kaufmann, P. J. 1992. The impact of managerial performance decay on franchisors' store allocation strategies, Journal of Marketing Channels 1(4): 51-79.

http://dx.doi.org/10.1300/J049v01n04_05

Kaufmann, P. J. 1996. The state of research in franchising, Franchising Research: an International Journal 1(1): 4-7.

Kaufmann, P. J.; Dant, R. P. 1996. Multiple-unit franchising: growth and management issues, Journal of Business Venturing 11(5): 343-358. http://dx.doi.org/10.1016/0883-9026(96)00057-2

Kaufmann, P. J.; Eroglu, S. 1998. Standardization and adaptation in business format franchising, Journal of Business Venturing 14: 69-85. http://dx.doi.org/10.1016/S0883-9026(97)00097-9

Kaufmann, P. J.; Kim, S. H. 1993. Master franchising and system growth rates, in The $7^{\text {th }}$ Annual Society of Franchising Conference, Excellence '93: A Bridge to Success, 7-8 February, 1993, San Francisco, CA.

Kaufmann, P. J.; Kim, S. H. 1995. Master franchising and system growth rates, in P. J. Kaufmann, R. P. Dant (Eds.). Franchising: contemporary issues and research. New York: Harvard Press, 49-64.

Lafontaine, F. 1992. Agency theory and franchising: some empirical results, RAND Journal of Economics 23: 263-283. http://dx.doi.org/10.2307/2555988

Lafontaine, F.; Slade, M. 1996. Retail contracting and costly monitoring: theory and evidence, European Economic Review 40(3/5): 923-932. http://dx.doi.org/10.1016/0014-2921(95)00101-8

Lowell, B. H. 1991. Multiple-unit franchising: the key to rapid system growth. Washington, DC: International Franchise Association.

Mathewson, G. F.; Winter, R. A. 1985. The economics of franchise contracts, Journal of Law \& Economics 28(3): 503-26. http://dx.doi.org/10.1086/467099

Minkler, A. 1992. Why firms franchise: a search cost theory, Journal of Institutional and Theoretical Economics 148: 240-259.

Nair, S. K.; Tikoo, S.; Liu, S. 2009. Valuing exclusivity from encroachment, Journal of Retailing 85(2): 206-210. http://dx.doi.org/10.1016/j.jretai.2008.07.004

Nani, A. J.; Dixon, J. R.; Vollman, T. E. 1990. Strategic control and performance measurement, Journal of Cost Management Summer: 33-42.

Norton, S. 1988. An empirical look at franchising as an organisational form, Journal of Business 61(2): 197-217. http://dx.doi.org/10.1086/296428

O'Cass, A. 2002. Political advertising believability and information source value during elections, Journal of Advertising 31(1): 63-74. http://dx.doi.org/10.1080/00913367.2002.10673661

Oxenfeldt, A. R.; Kelly, A. O. 1969. Will successful franchise systems ultimately become whollyowned chains?, Journal of Retailing 44(4): 69-83. 
Pehrsson, A. 2007. Business relatedness in international settings: performance effects in two customer contexts, in The Annual Meeting of the Academy of Management, 5 August, 2007, Philadelphia, USA.

Purbey, S.; Mukherjee, K.; Bhar, C. 2007. Performance measurement system for healthcare processes, International Journal of Productivity and Performance Management 56(3): 241-251. http://dx.doi.org/10.1108/17410400710731446

Reynolds, J. 2004. Economics 101: how franchising makes music for the U.S. economy, Franchising World 36(4): 37-40.

Robicheaux, R. A.; Dant, R.; Kaufmann, P. 1994. Multiple unit franchising in the fast food industry in the united states: incidence and operating characteristics, in S. Swerdlow (Eds). The 8th Conference of the Society of Franchising, 1994, Las Vegas, USA.

Roh, Y. S.; Andrew, W. P. 1997. Sub-franchising: a multiple-unit alternative to traditional restaurant franchising, Sales and Marketing December: 39-45.

Sen, K. C. 1998. The use of franchising as a growth strategy by USP restaurant franchisors, Journal of Consumer Marketing 15(4): 397-407. http://dx.doi.org/10.1108/07363769810226037

Sen, K. C. 2001. Information asymmetry and the franchise decision, Journal of Marketing Channels 8(1/2): 91-109. http://dx.doi.org/10.1300/J049v08n01_05

Shane, S. 2001. Technological opportunities and new firm creation, Management Science 47(2): 205-220. http://dx.doi.org/10.1287/mnsc.47.2.205.9837

Snyder, R. A.; Morris, J. H. 1984. Organizational communication and performance, Journal of Applied Psychology 69(3): 461-465. http://dx.doi.org/10.1037/0021-9010.69.3.461

Sorenson, O.; Sorenson, J. B. 2001. Finding the right mix: organisational learning, plural forms and franchise performance, Strategic Management Journal 22: 713-724.

http://dx.doi.org/10.1002/smj.185

Stern, L.; El-Ansary, A. 1988. Marketing channels. Englewood Cliffs, NJ: Prentice Hall.

Storm, M. 2008. A tale of two franchise expansionary strategies, Franchise Update 1: 53-54.

Tabachnick, B. G.; Fidell, L. S. 2001. Using multivariate statistics. $4^{\text {th }}$ ed. Boston: Allyn and Bacon.

Tenenhaus, M.; Vinzi, V. E.; Chatelin, Y-M.; Lauro, C. 2005. PLS path modeling, Computational Statistics \& Data Analysis 48: 159-205. http://dx.doi.org/10.1016/j.csda.2004.03.005

Tiessen, J. H.; Linton, J. D. 2000. The JV dilemma: cooperating and competing in joint ventures, Canadian Journal of Administrative Sciences 17(3): 203-216.

http://dx.doi.org/10.1111/j.1936-4490.2000.tb00221.x

Vandenbosch, M. B. 1996. Confirmatory compositional approaches to the development of product spaces, European Journal of Marketing 30(3): 23-46.

http://dx.doi.org/10.1108/03090569610107418

Watson, A.; Stanworth, J.; Purdy, D.; Healeas, S.; Holden, R. 2007. Multi-unit franchising: Implications for theory and practice, in R. Strassen (Eds.). The $21^{\text {st }}$ Annual International Society of Franchising Conference, 24-25 February, 2007, Minneapolis: MN, ISOF: University of St. Thomas.

Watson, J. 2002. Comparing the performance of male-female controlled business: relating outputs to inputs, Entrepreneurship Theory and Practice 26(3): 91-101.

Weaven, S. 2004. Factors influencing the decision to adopt multiple unit franchising arrangements. PhD Thesis, Griffith University, Queensland.

Weaven. S.; Frazer, L. 2003. Predicting multiple unit franchising: a franchisor and franchisee perspective, Journal of Marketing Channels 10(3): 53-82. 
Weaven, S.; Frazer, L. 2006. Investment incentives for single and multiple unit franchisees, Qualitative Market Research: an international Journal 9(3): 225-242.

Weaven, S.; Frazer, L. 2007. Expansion through multiple-unit franchising, International Small Business Journal 25(2): 173-205. http://dx.doi.org/10.1177/0266242607074524

Weaven, S.; Grace, D.; Manning, M. 2009. Franchisee personality: an examination in the context of franchise unit density and service classification, European Journal of Marketing 43(1/2): 90-109. http://dx.doi.org/10.1108/03090560910923256

Whittemore, M.; Perry, R. 1998. Multiple-unit franchising, Nation's Business 1(1): 3.

Yin, X. 2006. Multi-unit ownership and geographic proximity: the diffusion of a new strategy in a franchising chain, in The $26^{\text {th }}$ Annual International Conference of the Strategic Management Society (SMS), 29 October - 1 November, 2006, Vienna, Austria.

Yin, X.; Zajac, E. J. 2004. The strategy/governance structure fit relationship: theory and evidence in franchising arrangements, Strategic Management Journal 25: 365-83.

http://dx.doi.org/10.1002/smj.389

Zietlow, D. S.; Hennart, J. F. 1996. The international distribution of franchises by US franchisors, CIBER Working Paper. University of Illinois at Urbana Champaign, 96-102.

Kelli BODEY, Dr, is a Lecturer in the Department of Marketing and a member of the Asia-Pacific Centre for Franchising Excellence at Griffith University. She holds a $\mathrm{PhD}$ in franchising specialising in the area of multiple-unit franchising arrangements. Dr Bodey is a member of the International Society of Franchising and has published her research in international academic refereed journals including the Journal of Services Marketing, Psychology and Marketing, Journal of Asia Pacific Business and International Management and Entrepreneurship Journal and is the co-author of the 2010 Franchising Australia Survey. Dr Bodey teaches marketing, strategic international marketing and entrepreneurial marketing in both undergraduate and postgraduate programs at the Griffith Business School.

Scott WEAVEN, Associate Professor, is Deputy Director of Griffith University's Asia-Pacific Centre for Franchising Excellence and currently teaches in the Department of Marketing, Griffith University. His research interests include franchising and small business management and his research has been published in international journals including the Journal of the Academy of Marketing Science, Journal of Retailing, European Journal of Marketing, Journal of Business Ethics and International Small Business Journal, amongst others.

Debra GRACE, Professor, teaches marketing at Griffith University, Gold Coast, Australia. She holds a Bachelor of Business with Honours in Marketing and Management and a $\mathrm{PhD}$ in Marketing. Her research and teaching interests lie within the services marketing, branding, franchising and consumer behaviour areas. As such, she has numerous publications within journals that have their focus in these areas such as Journal of Retailing, Journal of Service Research, Journal of Services Marketing, European Journal of Marketing, Psychology and Marketing, Journal of Retailing and Consumer Services and more. 